
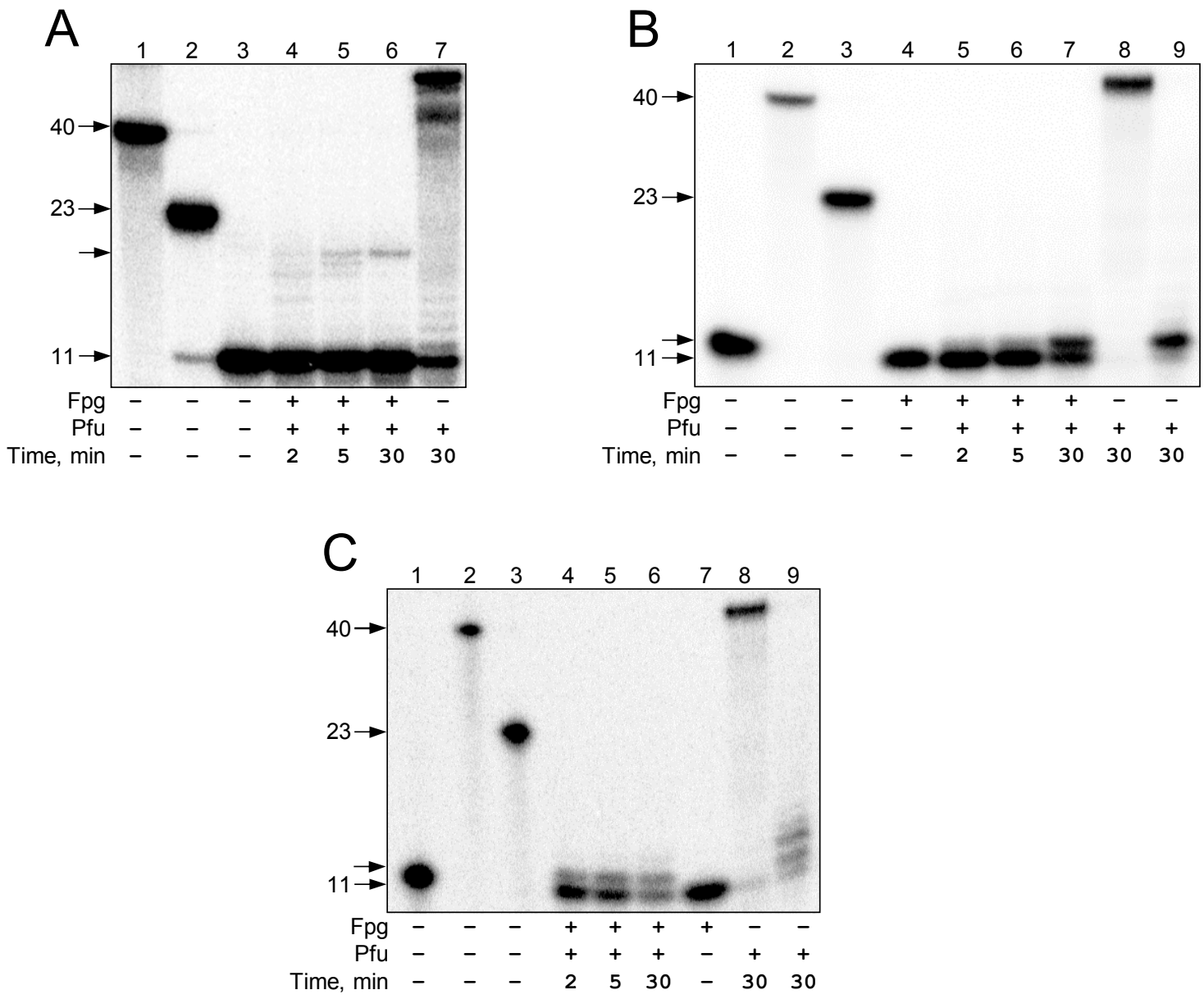

\title{
Supplementary Fig. 6.
}

Termination sites of Pfu DNA polymerase (Family B) at the DNA-protein cross-link in the template strand of single-stranded (A) or double-stranded DNA (B) and in the displaced strand of double-stranded DNA (C). Lanes 1-3, size markers (primer, $11 \mathrm{nt}$ long; primer extended to the cross-link site, $23 \mathrm{nt}$; full-size product, $40 \mathrm{nt}$ ); the arrows indicate their positions. The presence of DNA polymerase, cross-linked Fpg, and the reaction time are shown under the gel images. Control reactions were carried out with an undamaged substrate lacking (lane 7 in panel A; lane 8 in panels B, C) or containing (lane 9) the displaced strand. 